\title{
THE EFFECT OF USING POWERPOINT MODIFIED PICTURES IN WRITING DESCRIPTIVE TEXT TO THE EIGHTH GRADE STUDENTS OF SMPN 22 KOTA BENGKULU IN 2016/2017 ACADEMIC YEAR
}

\author{
Tri Susilo \\ Bengkulu University \\ tsusilo197@gmail.com \\ Kasmaini \\ Bengkulu University \\ kasmainiunib@gmail.com \\ Indah Damayanti \\ Bengkulu University \\ indah_078@yahoo.co.id
}

\begin{abstract}
This study aimed at investigatingthe effect of using powerpoint modified pictures as a media in teaching writing descriptive text. The population of this study was all the students of eighth grade students of SMPN 22 Kota Bengkulu in academic year 2016/2017 with the total number of population 66 students. The sample of this research was taken by using purposive sampling. By using that technique, 42 students were taken as the samples. The samples divided into two groups, experimental and control group. The instrument employed in this study was writing tests. The pre-test was conducted before giving treatments in order to know the scores of both groups. After giving some treatments to the experimental andcontrol group, the post-test was held to the both groups. Based on the data analysis of the post-test, it was found that $t$-count $>t$-table $(4.66>2.021)$. This finding indicated that there was a significant difference between the experimental and control group scores. It means that the null hypothesis $\left(\mathrm{H}_{0}\right)$ is rejected and the alternative hypothesis $(\mathrm{Ha})$ is accepted. In other words, powerpoint modified pictures had a significant effect on students' writing ability. The use of powerpoint modified pictures could increase students' writing ability especially in descriptive text. Therefore, this technique can be applied by teacher as a teaching aid in descriptive text's writing.
\end{abstract}

Keywords: powerpoint modified pictures, writing, descriptive text 


\begin{abstract}
Abstrak
Penelitian ini bertujuan untuk mengetahui pengaruh penggunaan gambar yang dimodifikasi dengan powerpoint sebagai media pembelajaran menulis teks deskripsi. Populasi dari penelitian ini adalah seluruh siswa kelas VIII SMPN 22 Kota Bengkulu tahun ajaran 2016/2017 dengan total siswa sebanyak 66 siswa. Sample dari penelitian ini diambil dengan teknik purposive sample. Dengan menggunakan teknik tersebut, 42 anak diambil sebagai sampel. Mereka dibagi menjadi dua kelompok, kelompok experimen dan kelompok kontrol. Instrumen yang digunakan dalam penelitian ini adalah test menulis. Sebelum melakukan perlakuan, pre-test dilakukan untuk mengetahui nilai awal dari dua kelompok. Setelah memberi perlakuan terhadap dua kelompok tersebut, kemudian post-test dilakukan pada dua kelompok tersebut. Berdasarkan analisis dari post-test, ditemukan bahwa nilai thitung > t-table $(4,66>2,021)$. Hasil ini mengindikasikan bahwa ada perbedaan yang signifikan antara dua kelompok tersebut. Ini berarti bahwa hipotesis nol $\left(\mathrm{H}_{0}\right)$ ditolak dan hipotesis alternatif (Ha) diterima. Dalam kata lain, gambar yang dimodifikasi dengan powerpoint memiliki pengaruh yang signifikan pada kemampuan menulis siswa. Penggunaan gambar yang dimodifikasi dengan powerpoint dapat meningkatkan kemampuan siswa dalam menulis terutama dalam menulis teks deskripsi. Oleh sebab itu, teknik ini dapat diaplikasikan oleh guru sebagai media pembelajaran dalam menulis teks deskripsi.
\end{abstract}

Kata kunci: gambar yang dimodifikasi dengan powerpoint, menulis, teks deskripsi

\section{INTRODUCTION}

There are four language skills to be mastered in English lesson.They are reading, writing, listening and speaking. Writing is one of those skills that must be mastered by students in learning English. The students are not only expected to master speaking skill, but they also must master writing skill to communicate with others.

However, sometimes writing is considered by some students as the most difficult skills to be mastered in learning English. Many students think that writing is complicated to be mastered. This is caused by some factors such as lack of vocabulary, difficulties in finding and developing their ideas and inability to write in good order. Besides that, they sometimes find the difficulties in the grammar and rule of language, because English grammar and rules are different from Indonesian rules. Whereas in educational curriculum in Indonesia writing is one of the aspects that are expected to be mastered by the eighth grade students of junior high school. They are expected to be able to write several genres of text; descriptive, recount and procedure text (Depdiknas, Indonesian Educational Department, 2013).

In this research the researcher will focus on descriptive text. According to Siahaan (2008) descriptive is a written English text in which the writer describes an object. Descriptive text is a kind of text that is used to describe something. The things that can be described such as particular person, place, animal, plants and many other things. It means that 
descriptive writing or descriptive text is a text that is used to describe something, it can be concrete or abstract object.

Descriptive text is considered as the simple text in learning English. Descriptive is saying what somebody or something is like. Therefore, descriptive text is a text that is used to describe what we see. It can be a particular person, place, animal and etc. However, some students still find the difficulties in writing descriptive text. They are confusing on how to write a descriptive text in a good order. They also find the difficulties in vocabulary mastery. Which make them are not able to develope their ideas in writing descriptive text.

While conducting the Internship 3 at SMP 22 Kota Bengkulu, the researcher observed the eighth grade students in that school. The material was about writing descriptive text. They were asked to describe an object such as animal, person, places, and etc. In that situation the students still found some difficulties, they are difficult in identifying and describing the object. They could not developed their ideas. They did not know well how to write descriptive text. They were lack of vocabulary and not really understand about how to use the adjectives word, auxiliry word and also plural-singular noun. Therefore, they always produce meaningless sentences. There are many factors causing students' lack of vocabulary, one of them is interest. Therefore, we need to create media wich can raise the students' interest. As teachers, we must be creative to choose the appropriate media to make the students more active and interested in learning procces.

From that phenomena, the researcher is interested to conduct the research about media that can be used in teaching writing descriptive text. The interesting media can gain the students' interest and attention in learning process. In this research, the researcher will conduct the research about the effect of using powerpoint modified pictures in writing descriptive text. The researcher will use a colourful pictures, both of animation and real pictures that modified by using powerpoint. Powerpoint is one of media that we can use to modify teaching media to be more interesting. Pictures is one of the media that we can modify by using powerpoint. The researcher will use this media in teaching writing descriptive text.

According to Schram and Wilbur in Madyawati (2016), Pictures are the imitation of thing, people that are universal, easy to understand and not bound by language. In addition, Hamalik (1986) states that picture is everything that is manifested visually in the form of two-dimensional as the outpouring of feelings or mind. From that definitions, we can conclude that pictures is shows us how something is. Pictures can replace the things or people we want to explain in the learning process. Pictures also represent our feeling and mind. Then, the researcher thinks that pictures is one of good media for teaching writing descriptive text. Besides, picture is not expensive media. We can find pictures in many places especially on the internet. Everyone will be able to find pictures especially for the teacher and students. By modified the pictures using powerpoint, the researcher hopes that students will be easier to identify and describe the object. The researcher will modified the pictures to be more interesting and clear in order to make the students more interest and easy to identify the object.

There are some previous studies that are related to this research. The first is the research conducted by Gustian Pelani from Bengkulu University with title"The 
Effect of Personal Photograph on Students' WritingQuantity in Descriptive Text." The result showed that personal photographs could increase students' writing quantity in writing descriptive text. The second is the research conducted by Sofia Winda Nur Fitriani in 2008 entittled "The Effectiveness of Using Pictures in Writing Descriptive Text to the Eight Grade Students Of Junior High School (A Case Study at the Eight Grade of SMP Negeri 26 Semarang in the Academic Year of 2008-2009)" the result was that pictures are effective media to improve descriptive writing skill in SMP N 26 Semarang. The third research was entittled "Using Pictures and Guided Questions in Teaching Descriptive Writing at the ODD Semester of VIII Grade Students at SMPN 111 Jakarta." The result showed that using picture with guided questioning could improve students' writing skill. The fourth research was conducted by SitiNur Hidayah in 2013 etitled "The Effect of Basic Questioning with Picture in Improving Student Writing Descriptive Text at SMPN 2 Paciran, Lamongan". The result showed that basic questioning with picture could improve students' skill in writing descriptive text.

The previous studies above suggested that pictures is a good media for teaching writing descriptive text. However, students still need more specific information about the object that they want to describe. They need more specific information to identify the object, because they lack of vocabulary. From that phenomena, the researcher is interested to conduct an experimental research about the effect of using powerpoint modified pictures in the eighth grade students of SMPN 22 Kota Bengkulu in the academic year 2016/2017. The difference of this research from the previous research is the media or pictures that use in this research is more than just a simple picture, but the picture with some additioal information. The pictures that will use by the researcher is both of animation and the real pictures which is modified by using powerpoint. The researcher will make the simple picture to be more interesting. By adding some effects, labels, and sounds on the pictures. The researcher hopes that this media will make the students more interest in learning and easier to identify the object that they want to describe. Besides, in SMPN 22 teaching by using powerpoint is very rarely done by the teacher. This study is intended to know how is the effect of using powerpoint modified pictures in writing descriptive text

\section{METHOD}

In this research, the researcher was using quasi-experimental method. Quasiexperiment is the design of the research which does not have full control. Nazir (2014)defines the experimental research as the research that is conducted by holding the manipulation of the research object as well as their control. The purpose of the experimental research is to determine whether there is a causal relationship or not, and to know how large that relation, by giving a certain treatment on several experimental groups and provide a control group for comparison. Sugiyono (2010) defines the experimental research as the research method that isconducted to find out the effect of particular treatment to the other in controled condition.

The population of this research was the Eighth Grade Students of SMPN 22 Kota Bengkulu in the academic year 2016/2017. There are three classes in eighth grade.They are VIII-A, VIII-B, 
and VIII-C. Each class consists of 20 to 24 students. The A class consists of 24 students, B class consists of 20 , and C class consists of 22 students. The total number of the populations is 66 students.In this research, the researcher selected the sample by using using purposive sampling. According to Sugiyono (2011) the purposive sampling is the technique of sampling that use for particular consideration. It is a sampling technique in which researcher relies on researcher's own judgment when choosing members of population to participate in the study. There are two classes of Eighth grade students of SMPN 22 Kota Bengkulu as the sample. The VIII-C class consist of 22 students was theexperimental group and VIII-B class consist of 20 students was the control group, the total sample are 42 students.

The instruments of this research was pre-test and post-test. This test have been conducted to find out the students' writing score. The score was from the result of the pre-test and post-test that are done by the students. The score was the datato be analyzed by the researcher. The test was about writing descriptive text, and the theme is about animal, person and place. The researcher gave the students 30 minutes to finish the test. The pre-test wasconducted before the treatment, and the post-test was conducted after the treatment in the experimental class by teaching writing descriptive text using powerpoint modified pictures as teaching media and the control group was thaught byusing traditional technique. The researcher was used content validity. Before the researcher gave the instrument to the sample of this study, the instrument validity was examined by expertwho has capability and usually teach writing skill.

The data of this research was collected from the result of pre-test and post-test. The researcher conducted both of these tests to collect the data. These are the procedure of collecting the data: (1) Preparing the instrument of the research. (2) Conducting the pre-test, in order to measure the score before the treatment. (3) Giving the treatment to the experimental group. (4) Conducting the post-test to know the score after giving a treatment. (5) Analyzing the score of the pre-test and post-test. (6) Discussing and making a conclussion based on the result of the data analysis.

The technique of analyzing data that used was the formuladeveloped by Arikunto (2010). The steps are following: (1) Calculating the mean of the pre-test and post-test from the experimental group and control group. (2) Calculating the standard deviation of the pre-test and post-test. (3)find out the significant difference between the pre-test and posttest used t-test formula. (4) Calculated the number of degree of freedom. Finally, after all steps was done it was found the $t_{v a l u e}$ from both of groups than the $t$ value checked with critical value of $t_{\text {table }}$ at standard of significance $=0,05$ level of significant of t-test.

\section{RESULTS}

Pre-test in the experimental group was attended by 22 students and control group was attended by 20 students and so was the post-test. The pre-test was given at the first meeting while the post test was conducted in the last meeting. After the test scores were collected, they were analyzed statistically to inform the finding of the research. The result of Pretest Score and Mean were presented in the following table: 


\begin{tabular}{|c|c|c|c|}
\hline Group & $\sum$ student & $\begin{array}{c}\text { Total } \\
\text { score }\end{array}$ & Mean \\
\hline $\begin{array}{c}\text { Experimental } \\
\text { groups }\end{array}$ & 22 & 1685 & 76.59 \\
\hline $\begin{array}{c}\text { Control } \\
\text { groups }\end{array}$ & 20 & 1215 & 60.75 \\
\hline
\end{tabular}

The table shows that the sum of the pre-test scores was 1250 for the experimental groups and 1060 for the control groups. The mean of the pretest scores of the experimental group was 56.81 and the control group was 53.00. It means that the students of the two groups have slight difference of ability in writing before the treatments were given. The difference was only 3.81. The mean scores from both groups could not achieve the minimum completeness critera (KKM), the minimum completeness criteria for eighth grade students is 75 . Here, the students faced some problems in writing descriptive text. They got difficulty to start writing because they did not have any idea and imagination even when they were helped by some pictures. Some of them were poor in grammar and vocabulary and it made them got difficulties in arranging the sentences into good order.

After the pre-test, the experimental group was given the treatment by teaching them using powerpoint modified pictures as teaching media. The treatment was given by the researcher. The English teacher also taught in the control group. However, she did not use the technique as in the experimental group; she used the traditional technique that she usualy

\begin{tabular}{|c|c|c|c|c|c|}
\hline \multirow{2}{*}{ Group } & \multirow{2}{*}{$\sum_{\text {st }}$} & \multicolumn{2}{|c|}{ Pre-test } & \multicolumn{2}{c|}{ Post-test } \\
\cline { 3 - 6 } & & $\begin{array}{l}\text { Total } \\
\text { score }\end{array}$ & Mean & $\begin{array}{c}\text { Total } \\
\text { score }\end{array}$ & Mean \\
\hline Ex & 22 & 1250 & 56.81 & 1685 & 76.59 \\
\hline Contr & 20 & 1060 & 53.00 & 1215 & 60.75 \\
\hline
\end{tabular}

applied before this research. After the treatments, the post-test was conducted to both groups. The result of the post-test

\begin{tabular}{|c|c|c|c|}
\hline Group & $\sum$ student & $\begin{array}{c}\text { Total } \\
\text { score }\end{array}$ & Mean \\
\hline $\begin{array}{c}\text { Experimen } \\
\text { tal groups }\end{array}$ & 22 & 1250 & 56.81 \\
\hline $\begin{array}{c}\text { Control } \\
\text { groups }\end{array}$ & 20 & 1060 & 53.00 \\
\hline
\end{tabular}

score and mean of the experimental and control groups were presented in the following table:

The table shows that the sum of the post-test scores was 1685 for the experimental groups and 1215 for the control groups. The mean of the post-test scores of the experimental group was 76.59 and the control group was 60.75 , the difference was 15.84. Compared with the mean difference of pre-test, the pretest higher than pre-test. The mean scores for the experimental groups also could passed the minimum completeness critera (KKM) 75.

From the result of pre-test and post-test scores, we could see that both groups have the improvement in the post-test. This can be influenced by several factors. For example, theyhave already learnt about descriptive text in seventh grade, so they just recall their knowledge about descriptive text. The technique in teaching and the students' condition also could influence the result. However, this study only concerns on the effect of using powerpoint modified pictures as a media in teaching descriptive text writing. The overall improvement between pre-test and post-test score of the experimental group was higher than the control group, and it could passed the minimum completeness critera (KKM) 75. The scores is presented in the following table:

Ex: experimental group, contr: control group, st: students. 
The researcher used t-test formula to compare the two mean scores between experimental and control groups. Before processing the data into formula, the mean score and standard deviation for experiment and control group should be found. After that, the data were put into the t-test formula.

After collecting the data, the researcher calculated the mean score of experimental and control groups. From the calculation, the mean score of experimental group was 19.8 , while the mean score of control group was 7.8. It shows that there is significant difference in mean score between experimental and control groups. In this case, the result of experimental group is higher than control group. The standard deviation for experimental group was about 823.87, while the control group was 573.75. After getting the mean and standard deviation of experimental and control group, t-test formula was used to find if there is significant mean difference between both classes.

Based on the calculation of t-test, the result of t-value is 4.66. This value was then compared to t-table distribution with the significant level of $0.05(5 \%)$ and degree of freedom 40 . The value in the $\mathrm{t}$ table is 2.021. So, it is clear that the $t-$ value is higher than the t-table (4.66compared to 2.021).This indicates that there is significant difference in the achievement between the students who were taught by using powerpoint modified pictures in the experimental group and those who were taught by using traditional technique in the control group. In other words, the treatments by using powerpoint modified pictures have significant effect to the students' scores in writing descriptive text.

The last steps $t_{\text {valuewere compared to }} t_{\text {table }}$. The result of $\mathrm{t}_{\text {value }} 4.66$ is higher than $\mathrm{t}$-table with the level significance of $5 \%$ and degree of freedom 40. By looking at the calculation above which states $\mathrm{t}$ value $>\mathrm{t}$ table (4.66> 2.021), then the conclusion is that the null hypothesis $\left(\mathrm{H}_{0}\right)$ is rejected and the alternative hypothesis ( $\mathrm{Ha})$ is accepted. This means that the powerpoint modified pictures have significant effect to the students' ability in writing descriptive text.

\section{DISCUSSIONS}

In the experimental class, the treatment was given in six meetings. They were taught byusing powerpoint modified pictures as teaching media in writing descriptive text, while the control group was thaught by using traditional technique. By seeing the result of pre-test, the researcher concluded that the students did not know well how to write descriptive text. They were lack of vocabulary and not really understand about how to use the adjectives word, auxiliry word and also plural-singular noun. Therefore, they always produce meaningless sentences. Based on the problems, then the researcher designed powerpoint modified pictures as teaching media by adding some materials about adjectives word, auxiliry word and also plural-singular noun to improve their skills in writing descriptive text.

During the treatment in the control group, the researcher did an observation in order to know the students' attention and reaction during the teaching learning process. Compared with the control group, the researcher found that the students in the experimental group were more interested in teaching learning process. They feel that it is an interesting activity since the teacher never used power pointin teaching learning process before this research. They also interested in the pictures and the theme that shown on the power point modified pictures. It 
proved the theory of Madyawati (2016), she said that there are some benefits from the pictures as a visual media: pictures can create the students' interest, to make easier the understanding, clarify the important parts and shorten a lengthy narrative. They also more active in answer the teacher's questions. It helps them to improve their ability in writing descriptive text.

By modifying the pictures using powerpoint, the teacher was easier to gain the student's attention. Students was also easier to identify the object, because the pictures was devided into several parts, for example the body parts, the characteristics and more details information about the pictures. Students also can remember the information easily, because they were interest to the media given by researcher. It showed by their enthusiasm in predicting what next words about the description of the picture that shown in the powerpoint.

Post-test was conducted on two classes in the last meeting. The researcher conducted the pre-test and post-test to both of classes of experimental and control was aimed to find out the students ability in writing descriptive text before and after the treatment in both of two groups. The result of students' achievement could be seen from the pretest and post-test result. While the results of pre-test indicates similar mean scores of the two groups, indicates similar ability in writing before the treatment, the mean scores of the post test show different values. The mean score of the experimental group was higher than the control group.

The result of all statistical analysis showed that the application of powerpoint modified pictures is more effective than traditional technique. It can be proved by the result of the calculation of t-test, the result of t-value is 4.66. This value was then compared to t-table distribution with the significant level of $0.05(5 \%)$ and degree of freedom 40 . The value in the ttable is 2.021. So, it is clear that the tvalue is higher than the t-table (4.66 compared to 2.021).

This indicates that there is significant difference in the achievement of the students. The experimental group achieved higher scores than the control group. By using powerpoint modified pictures, students' writing ability especially in writing descriptive text is better. The technique helps the students to lead their ideas, found new vocabulary and help them to have critical thinking. The students also found that using powerpoint modified pictures was interesting in learning writing descriptive text. In the process of teaching learning activity, the students pay more attention to the lesson.

The result of this study proved the theory of Daryanto (2016), he states that media is everything that can be used to convey the message (learning materials) so it can stimulate the students' attention, motivation, ideas, and the students' feeling in learning activity to achieve the goal of learning. It means that media can helps the students to pay more attention and motivation. Furthermore, Samidino et al. in Madyawati (2016)states thatpictures give an idea of something like pictures of animals, people and flowers. It also lead their ideas and the feeling in learning activity. Then, they can improve their ability in writing descriptive text.

Compared with the previous studies, the study conducted by Fitriani (2009) the result showed that pictures are effective media to improve descriptive writing skill in SMP N 26 Semarang. The second research conducted by Hidayah (2013), the result showed that basic questioning 
with picture could improve students' skill in writing descriptive text. However, students still need more specific information about the object that they want to describe. They need more specific information to identify the object, because the lack of vocabulary. Besides, students still need more interesting media to make them interest in learning. Especially in SMPN 22 Kota Bengkulu, because the teacher was very rarely used powerpoint in teaching learning process. Furthermore, the researcher hopes that powerpoint modified pictures could help the teacher of SMPN 22 Kota Bengkulu as the media in teaching English especially in teaching writing descriptive text.

\section{CONCLUSIONS}

Based on the results and discussions of the research, it can be concluded that teaching writing descriptive text by using powerpoint modified pictures has a positive effect on students' writing ability, especially in writing descriptive text. It can be seen by the result of $t^{-}$test which is higher than $t_{-}$table $(4.66>2,021)$. Thus, alternative hypothesis (Ha) is accepted. The result of the research shows that the students who are taught by using powerpoint modified pictures get better score than who are taught by traditional technique. It can be concluded that powerpoint modified pictures has been successfully implemented as an interesting media to improve students' writing ability, especially in writing descriptive text. In addition, it can affect students' writing skill in term of content, grammar, vocabulary and mechanic.
Based on the result of this research, some suggestions are proposed as follow: The result of this research showed that powerpointmodified pictures has the significant effect for students' abilityin writing descriptive text. The researcher suggests to the English teachers for applying this media to help the students in improving their writing ability.Not only in writing descriptive text but also in other kinds of text.

For further researchers, the result of this research can bethe reference in doing research in different subject and location for writing improvement and also to strengthen the findings.

\section{REFERENCES}

Fitriani, S.W. (2009). The Effectiveness of Using Pictures in Writing Descriptive Text to the Eight Grade Students Of Junior High School (A Case Study at the Eight Grade of SMP Negeri 26 Semarang in the Academic Year of 2008-2009). Semarang : UNS.

Hamalik, O. (1986). Media Pendidikan. Bandung: Alumni.

Hidayah, S.N. (2013). The Effect of Basic Questioning with Picture in Improving Student Writing Descriptive Text at SMPN 2 Paciran, Lamongan. Unpublished Thesis. Uin Sunan Ampel Surabaya.

Kurniawan, I. (2008). Using Pictures and Guided Questions in TeachingDescriptive Writing at the ODD Semester of VIII Grade Students at SMPN 111 Jakarta. Jakarta: UIN Syarif Hidayatullah. 
Madyawati, L. (2016). Strategi Pengembangan Bahasa Pada Anak. Jakarta : Kencana.

Nazir, M. (2014). Metode Penelitian. Ciawi, Bogor: Ghalia Indonesia.

Pelani, G. (2015). Journal of Linguistics and Language Teaching Vol.2: The Effect of Personal Photograph on Students' Writing Quantity in Descriptive Text (A Quasi-Experimental Study on the Second Year Students of SMAN 8 Bengkulu in 2006/2007 Academic Year). Bengkulu : Bengkulu University.

Siahaan, S. (2008). Issues In Linguistics (First Edition). Yogyakarta: Graha Ilmu.

Siahaan, S \& Shinoda, K. (2008). Generic Text Structure (First Edition). Yogyakarta : Graha Ilmu.

Sugiyono. (2010). Metode Penelitian Kuantitatif Kualitatif dan $R \& D$. $10 \mathrm{Ed}$. Bandung: Alfabeta.

Sugiyono. (2011). Metode Penelitian Kuantitatif, Kualitatif dan $R \& D$. Bandung, Alfabeta. 